\title{
PENGARUH KOMPRES DINGINTERHADAP TINGKAT NYERI SAAT PEMASANGAN INFUS PADA ANAK USIA SEKOLAH
}

\section{THE EFFECT OF COLD COMPRESS ON LEVELS PAIN DURING INFUSION INSTALLATION IN SCHOOL-AGE CHILDREN}

\author{
I Gusti Ayu Putu Satya Laksmi1 , Ni Made Suryati2, Ni Luh Gede Puspita \\ Yanti3. \\ Sekolah Tinggi Ilmu Kesehatan Wira Medika Bali123
}

\begin{abstract}
ABSTRAK
Pendahuluan:Prosedur pemasangan infus pada anak usia sekolah merupakan prosedur invasifyang mengakibatkan nyeri. Nyeri yang tidak ditangani dapat menimbulkan kesulitan tidur, ansietas, ketidakberdayaan dan keputusasaan. Kompres dingin merupakan salah satu tindakan keperawatan yang mampu mengurangi nyeri dengan memberikan efek anestesi lokal pada area yang akan dipasang infus. Penelitian ini bertujuan mengetahui pengaruh kompres dingin terhadap tingkat nyeri saat pemasangan infus pada anak usia sekolah. Metode:Desain penelitian menggunakan true eksperimental, dengan rancangan posttest-only control design. Teknik pengambilan sampel menggunakan consecutive sampling dengan sampel sebanyak 20 responden terbagi menjadi dua kelompok (10 responden kelompok kontrol dan 10 responden kelompok perlakuan).Kompres dingin dilakukan selama 3 menit sebelum pemasangan infus dilakukan.Hasil:Hasil penelitian menunjukkan rata-rata tingkat nyeri anak pada kelompok kontrol 6,4 termasuk nyeri sedang. Rata-rata tingkat nyeri pada kelompok perlakuan 2,7 termasuk nyeri ringan. Beda rata-rata tingkat nyeri pada kelompok perlakuan dan kelompok kontrol sebesar 3,7. Diskusi:Hasil uji Independent $T$ Test didapatkan $p$ value 0,000 , menunjukkan ada pengaruh kompres dinginterhadap tingkat nyeri saat pemasangan infus pada anak usia sekolah di RSUD Sanjiwani Gianyar. Kompres dingin saat pemasangan infus pada pasien anak diharapkan dapat dijadikan standar, sehingga dapat menurunkan nyeri pada pasien anak.
\end{abstract}

\section{Kata kunci:Anak usia sekolah, Kompres dingin, Tingkat Nyeri}

\section{ABSTRACK}

Introduction:The infusion procedure in school-age children is an invasive procedure that results pain. Pain that is not treated may cause anxiety, insomnia, powerlessness and hopelessness. Cold compress is one of the nursing interventions that are able toreduce pain by providing local anesthetic effect on the area where the infusion will be installed. The aim of the study to identify the effects of cold compress on levels of pain in school-age children during infusion installation.Method:Design of study was true experimental, with a posttest-only control design, by using consecutive sampling with 20 respondents consisted of two groups (10 control group and 10 intervention group). Cold compress was 
performed for 3 minutes prior infusion installation. Result:Results indicated that mean level of child pain in control group of 6,4 included moderate pain, mean level in intervention group of 2,7 included mild pain. Discussion:Bivariate analysis using Independent T Test.Mean difference of pain level in treatment and control group was 3,7 (p value 0,000), there are effects of cold compress on levels of pain during infusion installation in school-age children at Sanjiwani Gianyar hospital. Cold compresses during infusion in pediatric patients are expected to be standardized, by reducing pain in pediatric patients

Key word:School-age children, cold compress, Pain Level

\begin{tabular}{ll}
\hline Alamat Koresponden & $\begin{array}{l}\text { : Jalan Kecak No 9A Gatot Subroto Timur Denpasar } \\
\text { Email }\end{array}$ \\
\hline
\end{tabular}

\section{PENDAHULUAN}

Anak merupakan generasi penerus bangsa yang perlu diperhatikan status kesehatannya. Anak usia sekolah sangat rentan terhadap penyakit yang disebabkan karena faktor lingkungan, kebersihan, dan asupan gizi yang kurang sehat, sehingga lebih besar kemungkinan menderita penyakit. Anak yang mengalami sakit memerlukan pengobatan dan harus dirawat di rumah sakit (hospitalisasi) untuk proses penyembuhannya (Wong, 2012).

Berdasarkan data Perhimpunan Nasional Rumah Sakit Anak di Amerika, tahun 2014 sebanyak 6,5 juta anak/tahun yang menjalani perawatan di rumah sakit dengan usia 5-14 tahun (Utami, 2014). Hasil Riset Kesehatan Dasar (Riskesdas, 2013) persentase rawat inap di Indonesia sebesar 2,3\% dari seluruh penduduk Indonesia. Anak usia 5-14 tahun yang mengalami rawat inap karena menderita penyakit ISPA sebesar $15,4 \%$, penyakit TB paru sebesar $0,3 \%$, Hepatitis sebesar 0,2\%, Diare sebesar 5,1\%, Malaria sebesar 0,3\%, Asma sebesar 3,9\%, dan Kanker sebesar $0,1 \%$. Data Provinsi Bali menunjukkan proporsi pemanfaatan rawat inap pada anak yaitu sebesar $4,4 \%$. Proporsi pemanfaatan rawat inap pada kelompok umur 5-14 tahun menempati peringkat kedua sebesar 1,3\% setelah anak usia 0-4 tahun sebesar 2,8\% (Riskesdas Bali, 2013).

Anak yang harus mendapatkan perawatan di Rumah Sakit seringkali mendapatkan pengalaman dari berbagai prosedur invasif yang perlu dijalani. Prosedur pemasangan infus merupakan prosedur invasif yang sering dilakukan saat perawatan anak di rumah sakit, tindakan ini dilakukan dengan memasukkan jarum ke dalam pembuluh darah anak yang dapat mengakibatkan nyeri (Hockenberry \& Wilson, 2012).Pemasangan infus merupakan sumber kedua dari nyeri yang paling dirasakan anak setelah penyakit yang dideritanya (Indriyani, 2013).

American Heart Association (AHA) tahun 2012, menyatakan dampak yang ditimbulkan akibat prosedur tindakan invasive akan menimbulkan nyeri sehingga anak akan mengalami kecemasan dan stres. Nyeri yang tidak ditangani dapat berdampak besar pada kehidupan anak. Nyeri dapat mengganggu aktivitas anak sehingga anak kesulitan untuk berinteraksi dengan orang lain karena anak terfokus pada nyeri yang dirasakan. Dampak nyeri yang lain berupa kesulitan tidur, penurunan minat anak untuk melakukan kegiatan, dan meningkatnya kecemasan. 
Ketidakmampuan untuk mengurangi nyeri dapat menimbulkan ketidakberdayaan dan keputusasaan (Wong, 2012).

Upaya pengurangan nyeri dapat dilakukan melalui terapi farmakologik yaitu dengan menggunakan obat-obatan dan terapi non farmakologik tanpa menggunakan obat-obatan meliputi relaksasi, hipnotis, guided imagery, massage, terapi musik, kompres hangat dan kompres dingin (Dochter, 2013). Kompres dingin merupakan terapi nonfarmakologi yang cocok diberikan sebelum dilakukan pemasangan infus. Dingin akan menimbulkan mati rasa sebelum rasa nyeri timbul. Kompres dingin dapat menimbulkan efek anastesi lokal pada luka tusuk akibat pemasangan infus (Potter \& Perry, 2013). Kompres dingin menggunakan es memperlambat konduksi serabut saraf perifer dan menurunkan pelepasan mediator inflamasi dan nosiseptor sehingga menimbulkan efek anastesi kulit yang relatif cepat (Waterhouse, 2013).

Kompres dingin dipilih sebagai intervensi untuk mengurangi nyeri akibat pemasangan infus pada penelitian ini didasarkan pada hasil penelitian sebelumnya yang menunjukkan kompres dingin lebih efektif dibanding kompres hangat, serta berdasarkan teori Kozier (2012) yang mengatakan pada kompres dingin, pengalihan persepsi nyeri menjadi rasa dingin yang lebih dominan adalah salah satu tipe transendensi yang telah tercapai sehingga pasien merasa lebih nyaman, sedangkan pada kompres hangat tidak mempunyai efek yang sama dengan kompres dingin. Kompres hangat juga tidak mempunyai efek anestesi lokal yang dapat mengurangi nyeri lokal.

Data rekam medis RSUD Sanjiwani Gianyar menunjukan anak usia sekolah (6-12 tahun) yang dirawat di ruang Abimanyu pada tahun 2016 sebanyak 232 orang, dan meningkat pada tahun 2017 sebanyak 268 orang. Berdasarkan studi pendahuluan yang dilakukan peneliti di Ruang Abimanyu RSUD Sanjiwani Gianyar dari bulan November 2017 sampai bulan Januari 2018 didapatkan data dari 91 orang anak usia sekolah yang dirawat dan dilakukan pemasangan infus, ditemukan data bahwa keseluruhan anak tersebut mengalami nyeri. Tingkat nyeri anak diukur menggunakan skala penilaian nyeri menggunakan skala Face, Legs, Activity, Cry, Consolability (FLACC). Skala FLACC adalah suatu alat pengukuran rasa nyeri unidimensi berdasarkan tingkah laku pada anak kecil. Skala ini meliputi lima unsur yaitu wajah (Face), tungkai (Leg), gerakan (Activity), tangisan (Cry) dan dapat dihibur (Consolability) (Potter \& Perry, 2013).Hasil studi pendahuluan yang dilakukan pada bulan Februari 2018 dengan melakukan observasi terhadap 10 anak yang dilakukan pemasangan infus didapatkan delapan anak mengalami ketidaknyamanan/nyeri berat, dan dua anak yang mengalami ketidaknyamanan / nyeri sedang.

Upaya yang telah dilakukan di Ruang Abimanyu RSUD Sanjiwani Gianyar untuk mengatasi nyeri pada anak akibat pemasangan infus, antara lain menenangkan anak dengan cara menjelaskan tentang prosedur dan meyakinkan anak bahwa prosedur tersebut hanya mengakibatkan sedikit nyeri. Dampak dari usaha yang sudah dilakukan menurut penjelasan Kepala Ruangan yaitu dapat mengurangi ketakutan yang dirasakan oleh anak saat pemasangan infus, akan tetapi masih dijumpai kebanyakan anak yang menunjukkan respon terhadap nyeri seperti berteriak, menangis dan bertindak agresif seperti menggigit, memukul, menendang dan melarikan diri. Menurut Kepala Ruangan Abimanyu belum menerapkan penggunaan kompres dinginsaat pemasangan infuse dikarenakan terbatasnya 
sarana dan belum adanya Standar Prosedur Operasional (SPO) tentang penggunaan kompres dingin saat pemasangan infus.

Berdasarkan uraian di atas, penulis tertarik untuk melakukan penelitian dengan judul "pengaruh kompres dingin terhadap tingkat nyeri saat pemasangan infus pada anak usia sekolah di RSUD Sanjiwani Gianyar tahun 2018".

\section{BAHAN DAN METODE}

Rancangan dalam penelitian ini adalah true eksperimental, dengan rancangan posttest-only control design. Populasi pada penelitian ini semua anak usia sekolah yang dirawat dan dilakukan pemasangan infus di Ruang Abimanyu RSUD Sanjiwani Gianyar rata-rata sebanyak 30 orang perbulan dan semua anak usia sekolah yang dilakukan pemasangan infus di Unit Gawat Darurat (UGD)RSUD Sanjiwani Gianyar. Sampel dalam penelitian ini adalah anak usia sekolah yang dirawat dan dilakukan pemasangan infus di Ruang Abimanyu RSUD Sanjiwani Gianyar dan anak usia sekolah yang dilakukan pemasangan infus di Unit Gawat Darurat (UGD)RSUD Sanjiwani Gianyar, sebanyak 20 sampel, dengan tehnik pengambilan sampel dalam penelitian adalah Non-Probability Sampling jenis "Consecutive Sampling”. Instrumen yang digunakan yaitu prosedur pemasangan infus dengan kompres dingininstrumen untuk mengukur nyeri. Pelaksanaan penelitian dilakukan pada tanggal 8 April 2018 sampai dengan 8 Mei 2018. Analisis data untuk mengetahui pengaruh antara dua variable menggunakan uji Independent T Test.

\section{HASIL}

1. Karakteristik responden

Karakteristik responden yang diidentifikasi pada penelitian ini adalah umur, jenis kelamin, dan pengalaman infuse sebelumnya

Tabel 1 : Distribusi Responden Berdasarkan Umur diRumah Sakit Umum Daerah Sanjiwani Gianyar Tahun 2018

\begin{tabular}{lcccc}
\hline \multirow{2}{*}{ Umur } & \multicolumn{3}{c}{ Perlakuan } & \multicolumn{2}{c}{ Kontrol } \\
\cline { 2 - 6 } & $\mathbf{N}$ & $\mathbf{\%}$ & $\mathbf{N}$ & $\%$ \\
\hline 6 tahun & 3 & 30 & 4 & 40 \\
\hline 7 tahun & 1 & 10 & 2 & 20 \\
\hline 8tahun & 1 & 10 & 1 & 10 \\
\hline 9tahun & 2 & 20 & - & 0 \\
\hline 10 tahun & 2 & 20 & 2 & 20 \\
\hline 11 tahun & 1 & 10 & 1 & 10 \\
\hline 12 tahun & - & 0 & - & 0 \\
\hline \multicolumn{1}{c}{ Total } & 10 & 100 & 10 & 100 \\
\hline
\end{tabular}


Berdasarkan tabel 1, menunjukkan karakteristik responden berdasarkan umurpada kelompok perlakuan, mayoritas adalah umur 6 tahun sebanyak 3 orang (30\%), dan pada kelompok kontrol mayoritas adalah umur 6 tahun sebanyak 4 orang $(40 \%)$.

Tabel 2 : $\quad$ Distribusi Responden Berdasarkan Jenis Kelamin di Rumah Sakit Umum Daerah Sanjiwani Gianyar Tahun 2018

\begin{tabular}{lcccc}
\hline Jenis & \multicolumn{2}{l}{ Perlakuan } & \multicolumn{2}{l}{ Kontrol } \\
\cline { 2 - 5 } & $\mathbf{N}$ & $\mathbf{\%}$ & $\mathbf{N}$ & $\%$ \\
\hline Laki-laki & 5 & 50 & 7 & 70 \\
\hline Perempuan & 5 & 50 & 3 & 30 \\
\hline Total & 10 & 100 & 10 & 100 \\
\hline
\end{tabular}

Berdasarkan tabel 2, menunjukkan karakteristik responden berdasarkan jenis kelamin pada kelompok perlakuan, jumlahlaki-laki dan perempuan sama yaitu masing-masing sebanyak 5 orang (50\%), sedangkan pada kelompok kontrol sebagian besar laki-laki yaitu sebanyak 7 orang $(70 \%)$ dan perempuan sebanyak 3 orang $(30 \%)$.

Tabel 3 : Distribusi Responden Berdasarkan Pengalaman sebelumnya di Rumah Sakit Umum Daerah Sanjiwani Gianyar Tahun 2018

\begin{tabular}{lcccc}
\hline Pengalaman & \multicolumn{2}{c}{ Perlakuan } & \multicolumn{2}{c}{ Kontrol } \\
\cline { 2 - 5 } & $\mathbf{N}$ & $\mathbf{\%}$ & $\mathbf{N}$ & $\%$ \\
\hline Pernah & 2 & 20 & 2 & 20 \\
\hline Belum Pernah & 8 & 80 & 8 & 80 \\
\hline Total & 10 & 100 & 10 & 100 \\
\hline
\end{tabular}

Berdasarkan tabel 3, menunjukkan karakteristik responden berdasarkan pengalaman sebelumnya mengalami pemasangan infus pada kelompok perlakuan dan kelompok kontrol sebagian besar belum pernah mengalami pemasangan infus yaitu masing-masing sebanyak 8 orang $(80 \%)$ sedangkan yang pernah mengalami pemasangan infus masing-masing sebanyak 2 orang $(20 \%)$.

2. Hasil penelitian berdasarkan variabel penelitian

Variabel yang diukur pada penelitian ini adalah tingkat nyeri saat pemasangan infus pada kelompok perlakuan dan kontrol. 
Tabel 4 : Tingkat Nyeri Saat Pemasangan Infus Anak Usia Sekolah Setelah Diberikan Kompres Dingin Pada Kelompok Perlakuan di Rumah Sakit Umum Daerah Sanjiwani Gianyar Tahun 2018

\begin{tabular}{lc}
\hline Tingkat Nyeri & Hasil \\
\hline Mean & 2,7 \\
\hline Median & 3 \\
\hline Minimum & 1 \\
\hline Maksimun & 4 \\
\hline Standar deviasi & 0,9487
\end{tabular}

Berdasarkan tabel 4 menunjukkan rata-rata tingkat nyeri saat pemasangan infus pada kelompok perlakuan adalah 2,7 termasuk nyeri ringan, nyeri minimum 1 dan maksimum 4. Respon yang paling banyak diperlihatkan oleh anak saat pemasangan infus setelah diberikan kompres dingin adalah anak tampak meringgis, menggeliat-geliat serta memeluk orang tua.

Tabel 5 : Tingkat Nyeri Anak Usia Sekolah Pada Kelompok KontrolSaat Pemasangan Infus di Rumah Sakit Umum Daerah Sanjiwani Gianyar Tahun 2018

\begin{tabular}{lc}
\hline Tingkat Nyeri & Hasil \\
\hline Mean & 6,4 \\
\hline Median & 6,5 \\
\hline Minimum & 5 \\
\hline Maksimun & 8 \\
\hline Standar deviasi & 1,174 \\
\hline
\end{tabular}

Berdasarkan tabel 5 menunjukkan rata-rata tingkat nyeri saat pemasangan infus pada kelompok kontroladalah 6,4termasuk nyeri sedang, nyeri minimum 5 dan maksimum 8 . Respon yang paling banyak diperlihatkan anak saat pemasangan infus antara lain mengerutkan rahang, ada yang menendang, tampak tegang, dan menangis dengan keras bahkan ada anak yang sulit ditenangkan untuk dapat dipasangi infus.

Teknik analisa data yang digunakan untuk menguji hipotesis dengan menggunakan uji Independent t test karena berdasarkan uji normalitas data dengan menggunakan uji Shapiro-Wilk didapatkan hasil data post testpada kelompok perlakuan $\mathrm{p}=0,287>0.05$ danpost test kelompok kontrol didapatkan hasil $\mathrm{p}=$ $0,124>0.05$, hasil uji yang didapat menunjukkan data penelitian berdistribusi normal. Hasil uji levene's test didapatkan hasil sig $=0,309>0,05$ menunjukkan varian data kedua kelompok sama atau homogen sehingga prasyarat untuk menggunakan uji Independent t test terpenuhi.

Analisis data dilakukan untuk menganalisis pengaruh kompres dingin terhadap tingkat nyeri saat pemasangan infus pada anak usia sekolah di RSUD Sanjiwani Gianyar, hasil analisisnya adalah seperti terhadap tabel dibawah ini : 
Tabel 6 : Hasil Analisis Pengaruh Kompres DinginTerhadap Tingkat Nyeri Saat Pemasangan Infus Pada Anak Usia Sekolah di Rumah Sakit UmumDaerah Sanjiwani GianyarTahun 2018

\begin{tabular}{|c|c|c|c|c|}
\hline $\begin{array}{l}\text { Kelompok } \\
\text { sampel }\end{array}$ & $\mathrm{N}$ & Mean & $\begin{array}{l}\text { Nilai } \\
\text { beda } \\
\text { rata- } \\
\text { rata }\end{array}$ & $\begin{array}{l}\mathrm{p} \\
\text { value }\end{array}$ \\
\hline $\begin{array}{l}\text { Kelompok } \\
\text { Perlakuan }\end{array}$ & 10 & 2,70 & \multirow[b]{2}{*}{3,7} & \multirow[b]{2}{*}{0.000} \\
\hline $\begin{array}{l}\text { Kelompok } \\
\text { Kontrol }\end{array}$ & 10 & 6,40 & & \\
\hline
\end{tabular}

Berdasarkan tabel 6 hasil uji Independen T test didapatkan beda rata-rata tingkat nyeri saat pemasangan infus pada kelompok perlakuan dan kelompok kontrol sebesar 3,7 dan $p$ value $=0,000<0,05$ menunjukkan ada pengaruh kompres dingin terhadap tingkat nyeri saat pemasangan infus pada anak usia sekolah di RSUD Sanjiwani Gianyar.

\section{PEMBAHASAN}

1. Karakteristik dari responden penelitian (umur, jenis kelamin dan pengalaman sebelumnya)

Hasil penelitian ini menunjukkan karakteristik responden berdasarkan umur pada kelompok perlakuan mayoritas adalah umur 6 tahun sebanyak 3 orang (30\%), dan pada kelompok kontrol mayoritas adalah umur 6 tahun sebanyak 4 orang (40\%). Umur responden pada hasil penelitian ini menunjukan tingkat nyeri yang berbeda, hasil penelitian ini pada kelompok umur lebih kecil cenderung tingkat nyeri responden lebih besar dari pada kelompok umur yang lebih besar. Karakteristik responden berdasarkan pengalaman sebelumnya mengalami pemasangan infus pada kelompok perlakuan dan kelompok kontrol sebagian besar belum pernah sebelumnya mengalami pemasangan infus yaitu masing-masing sebanyak 8 orang $(80 \%)$, sedangkan yang pernah sebelumnya mengalami pemasangan infus masing-masing sebanyak 2 orang $(20 \%)$.

Pengalaman sebelumnya mengalami pemasangan infus pada hasil penelitian ini menunjukan kecenderungan yang sama dengan usia responden, dimana usia responden yang lebih kecil dan belum pernah mempunyai pengalaman sebelumnya mengalami pemasangan infus menunjukan tingkat nyeri yang lebih tinggi daripada usia responden yang lebih besar dan pernah mempunyai pengalaman sebelumnya mengalami pemasangan infus.

Usia adalah variabel penting yang mempengaruhi nyeri terutama pada anak, anak yang umurnya lebih kecil cenderung lebih sering sakit, anak yang umumnya mengalami sakit tidak hanya terganggu tumbuh kembangnya tetapi juga pendidikan anak tersebut (Soetjiningsih, 2012).Menurut Smeltzer \& Bare (2013) setiap individu belajar dari pengalaman nyeri, pengalaman nyeri sebelumnya tidak selalu berarti bahwa individu tersebut akanmenerima nyeri dengan lebih mudah di masa yang akan datang. 
Hasil penelitian ini memperkuat hasil penelitian sebelumnya yang dilakukan oleh Lestiawati (2016), yang menunjukan bahwa dari karakteristik usia responden didapatkan data anak usia sekolah awal (6-8 tahun) lebih banyak yang mengalami nyeri sakit paling sakit (skala nyeri 8 ), dibandingkan pada anak usia sekolah akhir (9-12 tahun) dan tingkat nyeri responden yang tidak pernah mengalami pemasangan infus sebelumnya mengalami tingkat nyeri yang lebih tinggi yaitu pada kategori sakit yang paling sakit dibandingkan responden yang pernah mengalami pemasangan infus sebelumnya.

Hasil penelitian ini menunjukkan karakteristik responden berdasarkan jenis kelaminpada kelompok perlakuan jumlah responden laki-laki dan responden perempuan sama yaitu masing-masing sebanyak 5 orang (50\%), sedangkan pada kelompok kontrol mayoritas laki-laki yaitu sebanyak 7 orang (70\%) dan perempuan sebanyak 3 orang $(30 \%)$. Perempuan secara konsisten melaporkan intensitas nyeri yang lebih tinggi, ketidaknyamanan, frustrasi, dan rasa takut, dibandingkan dengan laki-laki(Smeltzer \& Bare, 2013). Beberapa kebudayaan yang mempengaruhi jenis kelamin dapat mempengaruhi respon individu terhadap nyeri. Seorang anak lakilaki dalam budayanya dituntut untuk berani dan tidak boleh menangis, sedangkan anak perempuan diperbolehkan menangis dalam situasi yang sama (Potter \& Perry, 2013).

Hasil penelitian ini memperkuat hasil penelitian sebelumnya yang dilakukan oleh Asriani (2017) yang menunjukkan rata-rata tingkat nyeri responden berjenis kelamin perempuan lebih tinggi 0,38 dibandingkan rata-rata tingkat nyeri responden berjenis kelamin laki-laki.

2. Tingkat nyeri saat pemasangan infus anak usia sekolah pada kelompok perlakuan setelah diberikan kompres dingin

Hasil penelitian menunjukkan rata-rata tingkat nyeri saat pemasangan infus pada kelompok perlakuan adalah 2,7 termasuk nyeri ringan, nyeri minimum 1 dan maksimum 4. Menurut Waterhouse (2013) pemberian kompres dingin dapat menyebabkan pelepasan endorphin sehingga akan memblok transmisi stimulus nyeri. Kompres dingin menggunakan es memperlambat konduksi serabut saraf perifer dan menurunkan pelepasan mediator inflamasi dan nosiseptor sehingga menimbulkan efek anastesi kulit yang relatif cepat. Kompres dingin dapat menurunkan tingkat nyeri diperkuat oleh teori Tamsuri (2012) yang mengatakan pemberian kompres dingin dipercaya dapat meningkatkan pelepasan endorfin yang memblok transmisi stimulus nyeri memberikan efek menurunkan sensasi nyeri, kompres dingin juga memberikan efek fisiologis seperti menurunkan respon inflamasi jaringan, menurunkan aliran darah dan mengurangi edema.

Hasil penelitian ini memperkuat hasil penelitian sebelumnya yang dilakukan oleh Nurchairiah (2015) menunjukkan pada kelompok eksperimen ratarata intensitas nyeri sebesar 4,47, dan pada kelompok kontrol intensitas nyeri lebih tinggi yaitu sebesar 7,27.

3. Tingkat nyeri saat pemasangan infus anak usia sekolah pada kelompok kontrol yang tidak diberikan kompres dingin

Hasil penelitian ini menunjukkan rata-rata tingkat nyeri saat pemasangan infus pada kelompok kontrol termasuk nyeri sedang. Respon yang paling banyak diperlihatkan anak saat pemasangan infus antara lain mengerutkan rahang, ada yang 
menendang, tampak tegang, dan menangis dengan keras bahkan ada anak yang sulit ditenangkan untuk dapat dipasangi infus. Menurut Prasetyo (2013) saat jarum infus menusuk kulit akan menimbulkan rangsangan yang mengganggu sehingga akan mengaktifkan nosiseptor nyeri. Nosiseptor nyeri akan merangsang ujung saraf aferen untuk mengeluarkan substansi P. Substansi P yang dilepaskan akan mempengaruhi nosiseptor diluar daerah trauma yang akan menimbulkan lingkaran nyeri semakin meluas. Impuls nyeri akan ditransmisikan ke medula spinalis melalui jalur asendens. Ketika impuls nyeri masuk ke kornu posterior medula spinalis akan terjadi interaksi antar sistem analgesia endogen yang dihasilkan oleh tubuh. Jika nyeri tidak dihambat pada proses ini maka nyeri yang dirasakan akan lebih lama dan semakin meluas.

Hasil penelitian ini tidak sesuai dengan hasil penelitian sebelumnya yang dilakukan oleh Endiyono (2017) menunjukan bahwa pemberian kompres dingin dapat menurunkan skala nyeri pada insersi arteriovenosa fistula pada pasien dengan hemodialysis.

4. Pengaruh kompres dingin terhadap tingkat nyeri saat pemasangan infus pada anak usia sekolah

Berdasarkan hasil uji Independen $T$ test didapatkan beda rata-rata tingkat nyeri saat pemasangan infus pada kelompok perlakuan dan kelompok kontrol sebesar 3,7 dan $p$ value $=0,000<0,05$ menunjukkan ada pengaruh kompres dinginterhadap tingkat nyeri saat pemasangan infus pada anak usia sekolah di RSUD Sanjiwani Gianyar

Teori pertahanan nyeri gate control dari Melzack dan Wall menyatakan impuls nyeri dapat diatur atau dihambat oleh mekanisme pertahanan di sepanjang sistem saraf pusat. Pemberian kompres dingin akan menstimulasi alur saraf desenden melepaskan opiate endogen seperti endorphin yang merupakan pembunuh nyeri alami yang berasal dari tubuh. Pemberian kompres dingin juga dapat menstimulasi neuromodulator menutup mekanisme pertahanan dengan menghambat pelepasan substansi P (Potter \& Perry, 2013).

Menurut teori Kozier (2012) yang mengatakan pada kompres dingin, pengalihan persepsi nyeri menjadi rasa dingin yang lebih dominan adalah salah satu tipe transendensi yang telah tercapai sehingga pasien merasa lebih nyaman, sedangkan pada kompres hangat tidak mempunyai efek yang sama dengan kompres dingin. Kompres hangat juga tidak mempunyai efek anestesi lokal yang dapat mengurangi nyeri lokal. Prasetyo (2013) juga mengatakan kompres dingin bekerja dengan menstimulasi permukaan kulit untuk mengontrol nyeri. Kompres dingin yang diberikan akan mempengaruhi impuls yang dibawa oleh serabut taktil A-Beta untuk lebih mendominasi sehingga akan menutup dan impuls nyeri akan terhalangi. Nyeri yang dirasakan akan berkurang atau hilang untuk sementara waktu.Kompres dingin diketahui efektif dan efisien digunakan sebagai stimulasi kulit. Menurut Nurchairiah (2015), pada umumnya dingin lebih mudah menembus jaringan dibandingkan dengan panas. Ketika otot sudah mengalami penurunan suhu akibat aplikasi dingin, efek dingin dapat bertahan lebih lama dibanding dengan panas karena adanya lemak subkutan yang bertindak sebagai isolator, di sisi lain lemak subkutan merupakan barrier utama energi dingin untuk menembus otot.

Menurut Asriani (2017), menyebutkan kompres dingin selama 1-3 menit mampu menurunkan nyeri pada prosedur pemasangan infus anak usia sekolah. 
Hasil ini tidak jauh berbeda dengan pendapat Fauzi dan Hendayani (2013) yang menyatakan tentang mayoritas responden yang diberikan kompres dingin selama 3 menit mengalami nyeri yang lebih ringan. Indriyani (2013) menyebutkan penerapan kompres hangat selama 5 menit dan kompres dingin selama 5 menit terhadap nyeri pada anak usia sekolah saat pemasangan infus didapatkan hasil kompres dingin lebih efektif dalam menurunkan nyeri. Secara fisiologis, pada 10-15 menit pertama setelah pemberian kompres dingin terjadi vasokonstriksi pada pembuluh darah (Nurchairiah, 2015). Dalam bidang keperawatan kompres dingin banyak digunakan untuk mengurangi rasa nyeri. Kompres dingin memberikan efek fisiologis yakni menurunkan respon inflamasi, mengurangi nyeri bekerja dengan cara melepaskan endorfin, sehingga memblok transmisi stimulus nyeri (Potter \& Perry, 2013).

Hasil penelitian ini memperkuat hasil penelitian sebelumnya yang dilakukan oleh Indriyani (2013) yang meneliti tentang kompres dingin dapat menurunkan nyeri anak usia sekolah saat pemasangan infus. Hasil uji statistik dengan Anova menunjukkan ada perbedaan bermakna antara pengaruh pada ketiga kelompok terhadap skala nyeri $(p=0,0001 ; \alpha=0,05)$ dan hasil uji post hock menunjukkan bahwa pemberian kompres dingin mempunyai mean difference paling besar yaitu 4,267. Penelitian Nurchairiah (2015) menunjukkan bahwa terdapat perbedaan yang signifikan intensitas nyeri setelah diberikan kompres dingin antara kelompok eksperimen dengan kelompok kontrol, pada kelompok eksperimen rata-rata intensitas nyeri sebesar 4,47 dan pada kelompok kontrol intensitas nyeri lebih tinggi yaitu sebesar 7,27. Penelitian Hendayani (2013) tentang pengaruh kompres dingin terhadap tingkat nyeri pada prosedur invasif pemasangan infus anak usia sekolah di RS Bendan Kota Pekalongan. Hasil penelitian didapatkan $p$ value sebesar 0,002 ( a $<0,05)$ yang artinya ada pengaruh kompres dingin terhadap tingkat nyeri pada prosedur invasif pemasangan infus anak usia sekolah di RS Bendan Kota Pekalongan.

Peneliti berpendapatpemberian kompres dingin dapat menurunkan tingkat nyeri saat pemasangan infus karena tindakan kompres dingin memberikan efek fisiologis pada tubuh meredakan nyeri dengan membuat area menjadi mati rasa/ memberi efek anestesi lokal, dan memperlambat aliran impuls nyeri. Rata-rata tingkat nyeri pada kelompok intervensi lebih rendah dibandingkan dengan kelompok kontrol dapat disebabkan karena terjadi perbedaan kecepatan hantaran nyeri dari serabut saraf perifer ke otak. Tingkat nyeri kelompok intervensi lebih rendah karena kompres dingin dapat menghambat hantaran nyeri dari serabut perifer sampai ke otak. Saat dilakukan penelitian dengan memberikan kompres dingin selama 3 menit sebelum dilakukan tindakan pemasangan infus, pembuluh darah vena pada bagian tubuh yang telah diberi kompres dingin tidak mengalami vasokontriksi. Keadaan ini dibuktikan ketika jarum abocath ditusukan ke pembuluh darah vena, sebagai kontrol bahwa tindakan pemasangan infus telah berhasil ditandai dengan keluarnya darah pada mandrin abocath, mandrin ditarik kemudian selang infuset disambungkan pada abocath dan roll klem dibuka terlihat cairan infus menetes lancar. 


\section{Simpulan}

\section{SIMPULAN DAN SARAN} berikut:

Berdasarkan hasil penelitian di atas dapat dirumuskan kesimpulan sebagai

1. Karakteristik responden berdasarkan umurpada kelompok perlakuan dan kelompok kontrol mayoritas adalah umur 6 tahun. Karakteristik responden berdasarkan jenis kelamin pada kelompok perlakuan yaitu jumlahlaki-laki dan perempuan sama, sedangkan pada kelompok kontrol sebagian besar laki-laki. Karakteristik responden berdasarkan pengalaman sebelumnya pada kelompokperlakuan dan kelompokkontrol mayoritas belum pernah mengalami pemasangan infus.

2. Rata-rata tingkat nyeri saat pemasangan infus pada kelompok perlakuan adalah 2,7termasuk nyeri ringan, nyeri minimum 1 dan nyeri maksimum 4.

3. Rata-rata tingkat nyeri saat pemasangan infus pada kelompok kontroladalah 6,4termasuk nyeri sedang, nyeri minimum 5 dan nyeri maksimum 8 .

4. Hasil uji Independen $T$ test didapatkan beda rata-rata tingkat nyeri saat pemasangan infus pada kelompok perlakuan dan kelompok kontrol sebesar 3,7 dan $p$ value $=0,000<0,05$ menunjukkan ada pengaruh kompres dinginterhadap tingkat nyeri saat pemasangan infus pada anak usia sekolah di RSUD Sanjiwani Gianyar.

\section{Saran}

1. Bagi Rumah Sakit

Diharapkan pemberian kompres dinginsaat pemasangan infus terutama pada pasien anak dapat dijadikan standar dengan menindaklanjuti pembuatan Standar Operasional Prosedur pemasangan infus dengan pemberian kompres dingin.

2. Bagi tenaga Perawat

Metoda kompres dingin dapat dipertimbangkan sebagai salah satu tindakan non farmakologi yang dapat menurunkan nyeri pada pasien anak yang akan dilakukan tindakan pemasangan infus.

3. Bagi Peneliti Selanjutnya

Peneliti selanjutnya diharapkan dapat melakukan penelitian terkait dengan penerapan kompres dingin terhadap an invasif yang lain pada anak, dan mengkondisikan anak agar lebih koopı aı.

\section{DAFTAR PUSTAKA}

American Heart Association (AHA). 2012. Adult Basic Life Support: Guidelines for CPR and Emergency Cardiovascular Care, (online), (http://circ.ahajournals.org/content/122/18_suppl_3/S685, diakses tanggal 20 Pebruari 2018).

Asriani. 2017. Pengaruh Kompres Dingin Terhadap Tingkat NyeriAnak Usia Sekolah Saat Pemasangan Infus DiPoliklinik Persiapan Rawat Inap RSUDPanembahan Senopati Bantul. Jurnal Keperawatan Respati Yogyakarta, 4 (1), Januari 2017, 70-75

Dochter. 2013. Nursing Intervention, Classification (NIC) Sixth Edition. USA: Mosby.IN

Endiyono.2017. Pengaruh Kompres Dingin Terhadap Tingkat Persepsi Nyeri 
Insersi Arteriovenosa Fistula Pada Pasien Hemodialisis Di Rumah Sakit Umum Daerah Purbalingga.Jurnal Medika Respati Vol. 12 Nomor 3 Juli 2017

Hendayani.2013. Pengaruh Kompres Dingin Terhadap Tingkat Nyeri Pada Prosedur Invasif Pemasangan Infus Anak Usia Sekolah di RS Bendan Kota Pekalongan. Jurnal Keperawatan Respati Yogyakarta, 2 (1), Januari 2013, $10-55$

Hockenberry \& Wilson. 2012. Essential of Pediatric Nursing. St. Louis Missoury: Mosby

Indriyani. 2013.Kompres Dingin Dapat Menurunkan Nyeri Anak Usia Sekolah Saat Pemasangan Infus. Jurnal Keperawatan Indonesia, Volume 16 No.2, Juli 2013, hal 93-100

Kozier. B. 2012. Buku Ajar Praktik Keperawatan Klinis. Alih Bahasa: Eny Meiliya, Esty Wahyuningsih, dan Devi Yulianti. Jakarta: EGC.

Lestiawati. 2016. Faktor Yang Berhubungan Dengan Tingkat Nyeri Pemasangan Infus Pada Anak Usia Sekolah. Universitas Respati Yogyakarta

Nurchairiah. 2015. Efektifitas Kompres Dingin Terhadap Intensitas Nyeri Pada Pasien Fraktur Tertutup Di Ruang Dahlia Rsud Arifin Achmad. (online), Available: (http://repository.usu.ac.id/bitstream.pdf diakses tanggal 2 Maret 2018)

Potter, P.A. \& Perry, A.G. 2013. Buku Ajar Fundamental Keperawatan: Konsep, Proses dan Praktek, Alih Bahasa: Yasmin Asih. Jakarta: EGC

Prasetyo, S. N. 2013. Konsep dan Proses Keperawatan Nyeri. Yogyakarta: Graha Ilmu

Riskesdas. 2013. Data Riset Kesehatan Dasar. Jakarta : Kementerian Rebuplik Indonesia.

Riskesdas Bali. 2013. Data Riset Kesehatan Dasar Provinsi Bali. Dinas Kesehatan Provinsi Bali

Smeltzer \& Bare. 2013. Buku Ajar Keperawatan Medikal Bedah: Brunner\& Suddarth (edisi 8 ed., Vol.2). Jakarta: EGC

Soetjiningsih. 2012. Tumbuh KembangAnak. Jakarta: EGC

Tamsuri, Anas. 2012. Konsep Dan Penatalaksanaan Nyeri.Jakarta : EGC.

Utami. 2014.Dampak Hospitalisasi Terhadap Perkembangan Anak. Jurnal Ilmiah WIDYA Volume 2 Nomor 2 Mei-Juli 2014

Waterhouse. 2013. Cryotherapeutic Topical Analgesics For Pediatric Intravenous Catheter Placement: Ice versus Vapocoolant Spray. Pediart EmergCare.December.pp. 2.

Wong, D. L. 2012. Pedoman Klinis Keperawatan Pediatrik, Edisi 4. Jakarta: EGC. 